ISSN 0103-5150

Fisioter. Mov., Curitiba, v. 30, n. 2, p.227-235, Apr./June 2017

Licenciado sob uma Licença Creative Commons

DOI: http://dx.doi.org/10.1590/1980-5918.030.002.A003

(c)

\title{
Reflection on the public home care caregivers profiles
}

\section{Reflexão acerca do perfil de cuidadores da rede pública de assistência domiciliar}

\section{Heloísa Silva Guerra ${ }^{[a]}$, Nilza Alves Marques Almeida ${ }^{[b]}$, Marta Rovery de Souza ${ }^{[b]^{*}}$}

[a] Universidade de Rio Verde (FM/UniRV), Aparecida de Goiânia, GO, Brazil

[b] Universidade Federal de Goiás (FEN/UFG), Goiânia, GO, Brazil

\begin{abstract}
Introduction: The increase of life expectancy and the decrease in mortality rate have resulted in changes in the epidemiological profile with predominance of non-communicable chronic diseases and global changes in the care system. This scenario has generated increased demands for caregivers, which in Brazilian reality, tends to arise in the family environment. Objective: This study aimed to know and reflect on the caregivers' profiles of public home care in the city of Goiânia, Goiás. Methods: The data were collected through the application of a caregiver characterization tool and presented descriptively. Results: The caregiver's profile of this study corroborates the ones described in the specific literature. Most of them are females, married, patient's spouse or daughter, having health problems, dedicating twelve or more hours to caring and informal exercise of this activity. Conclusion: The results show the significance of family caregivers within the family care and lead to the reflection about this role in the care sphere and the need for public policies that offer a support social network and that are tuned with this reality.
\end{abstract}

Keywords: Home Nursing. Caregivers. Public Health Policy.

HSG: MS, e-mail: heloisasguerra@gmail.com NAMA: PhD, e-mail: nilzafenufg@gmail.com MRS: PhD, e-mail: martary@gmail.com 
Resumo

\begin{abstract}
Introdução: $O$ aumento da expectativa de vida e a diminuição da taxa de mortalidade têm resultado em mudanças no perfil epidemiológico com o predomínio de doenças crônicas não transmissíveis e mudanças no sistema de cuidados mundialmente. Esse cenário tem gerado o aumento da demanda de cuidadores, que na realidade brasileira, tende a surgir no próprio ambiente familiar. Objetivo: $O$ presente estudo buscou conhecer e refletir acerca do perfil de cuidadores da rede pública de assistência domiciliar do município de Goiânia, Goiás. Métodos: Os dados foram coletados por meio da aplicação de um instrumento de caracterização do cuidador e apresentados de forma descritiva. Resultados: O perfil do cuidador deste estudo corrobora com o descrito na literatura, sendo a maioria do sexo feminino, casado, cônjuge ou filho do usuário do serviço, com problemas de saúde, dedicação de mais de 12 horas ao cuidado e exercício informal desta atividade. Conclusão: Os resultados evidenciam a importância do cuidador familiar no âmbito da atenção domiciliar e remetem à reflexão sobre esse papel na esfera do cuidado, bem como a necessidade de políticas públicas que ofereçam uma rede social de apoio e que estejam afinadas com essa realidade.
\end{abstract}

Palavras-chave: Assistência Domiciliar. Cuidadores. Políticas Públicas de Saúde.

\section{Introduction}

It is a consensus that a new demographic model is present almost worldwide. The increase of life expectancy and the decrease of the mortality rate currently represent a global phenomenon that have as a result population ageing and consequences for social policies, representing one of the greatest challenges of contemporary public health $(1,2)$.

As in many countries, Brazil has experienced a situation of significant growth of the elderly population. The number of elderly increased from 3 million, in 1960 , to 7 million in 1975, and 23,5 million in 2011, representing a considerable increase. In addition, 650.000 new seniors are included to the population each year, and the most conservative projections indicate that by the year of 2020, Brazil will be the sixth country in the world in number of elderly, with more than 30 million people $(3,4)$. In this scenario the chronic non-communicable diseases (CNCD) also stand out as a global health problem and a threat to health and human development (5).

The phenomenon of population aging has resulted in changes in the epidemiological profile of the population, with the prevalence of CNCD in the care system. On the one hand this change has required the continuous increase of hospital beds, on the other, it has stimulated the home care since the creation of deinstitutionalization and humanization policies $(6,7)$.
The CNCD are a major obstacle to quality of life, since they result in reduced autonomy and independence and they also generate the need of specific cares, especially for the elderly (8). It is estimated that the number of Brazilian elderly who may need long-term care is expected to grow around 30\% to $50 \%$ between 2010 and 2020, depending on improvements or not in the autonomy conditions. This is a worrying situation, since the changes in the families profile have resulted in significant reduction of family caregivers (9).

Family has suffered the consequences towards the modernization process, such as changing the constitution of their arrangements, reduction on their component's number, increased participation of women in the labor market, and the emerging of new gender roles (8).

In Brazil the caregiver figure usually arises in the family environment mainly due to poorer socioeconomics conditions (10). Each family has its own way to face this situation, depending on the structure of the relationship between the diseased and the family members along the years. However, most of times women take on the role of primary caregiver accumulating this responsibility with household chores (6).

It is known that care permeates the concept of quality of life both concerning taking care of themselves as caring for others. In the second case, when there is a functional dependence of a subject, it mobilizes not only individual demands, but also family 
and social, which affect the routine and structure in which the subject is inserted, occurring this way, financial changes, changes of roles, among others (10).

The tasks assigned to the caregivers (many times without proper orientation and support from health institutions) associated with routine changes and to the time spent in care, have affected their life quality (11). Besides, depending on the level of involvement of the caregivers during care, they fail to give attention to their own needs. This can lead to physical, emotional, social and financial problems (12).

The growing demand for care, the changes in the family context and the impact on quality of life resulting from the caregiver's care process, point to the need for reflection on the family role in the context of care. This reflection also constitutes challenge for governments in order to develop public policies that meet the needs of home care and ensure adequate support for functionally dependent people.

Federal Government has encouraged and regulated the realization of home care with the implementation of the "Best Home" Program, in 2011. One component of this program is the Home Care Service (SAD, the acronym in Portuguese), that is a strategy to support the families of users of the Unified Health System (SUS, the acronym in Portuguese), chronic disease patients who are bedridden or with limited mobility and that need care with more frequency through continuous monitoring. However, to be admitted to the program, besides the clinical profile, the presence of a caregiver is mandatory the presence of a previously identified caregiver who is able to perform the actions agreed between the SAD team and user family $(13,14)$.

The SAD program, coordinated by the municipal public health care of Goiânia, Goiás, is composed of a multidisciplinary team of 32 professionals, including doctors, nurses, nursing technicians, speech therapists, physiotherapists, psychologists and nutritionists, who are distributed by health units according to the Health Districts Campinas-Central, Northwest, North, West, Southwest, South and East (15).

The performance of the SAD team in attention to SUS' users has favored obtaining knowledge about the health needs of this clientele and also of their caregivers because the SAD team witness the difficulties encountered to play this role.

Therefore, this study aimed to know and think over the caregivers' profile of public home care in the city of Goiânia, Goiás.

\section{Methods}

This study is part of a research entitled "Quality of life and caregivers work overload Home Care Service of Goiânia, Goiás". It is an analytical cross-sectional study in which home interviews were conducted with caregivers of the patients enrolled in the Home Care Service (SAD, the acronym in Portuguese) of Goiânia, between September 2012 and August 2013.

The study was approved by the Federal University of Goiás' Clinical Hospital's Research Ethics Committee with Opinion No. 86.194/12, in accordance with Resolution No. 466/12 of the National Health Council (16). It was guaranteed to all participants voluntary participation by reading and signing the Informed Consent Form - IC.

The sample consisted of 95 caregivers of a population of 113 users' caregivers registered and assisted by SAD. Eighteen caregivers did not participate in the study. Five refused to participate, three per death reasons, three because they move to other cities, two for not being the primary caregiver of the SAD user, two for being following hospitalized patients for over two months and three because they were not found at the given address in more than three consecutive visits.

For the present study were eligible the SAD caregivers aged over 18 years, literate, engaged in the primary caregiver function of the registered user for at least two months.

In order to characterize caregivers a compound formed by 17 closed questions, adapted from previous studies, was applied $(17,18)$. The questions allowed to investigate the lives of caregivers regarding gender, age, marital status, relationship to the elderly under their care, education (years of schooling), whether or not prior experience in caring, number of hours devoted to care, presence of some pathology, among others. The pathologies reported by the caregivers were self-reported.

The data handling was done using the software Statistical Package for Social Sciences 15.0 and descriptive analysis, with average presentation, median, standard deviation and absolute frequency and percentage of the variables in the table and figures.

\section{Results}

Table 1 presents the characteristics of 95 caregivers of registered and assisted users by the Home 
Care Service (SAD), of the municipal public network for health care from Goiânia-GO, aged between 19 and 82 years, with an average age of 49.7 years (DP \pm 13.0 ).

Regarding the caregiver role, most of them had no previous experience regarding the care giving activity; exercise the role of primary caregiver with dedication of more than 12 hours a day and providing continuous care without enjoying weekly days off, although with task division with others (Table 2).

Table 1- Distribution of characteristics of caregivers from Home Care Service. Goiânia - GO, 2013

\begin{tabular}{lcc}
\hline Caregiver characteristics & $\mathbf{n}$ & (\%) \\
\hline Gender & & \\
$\quad$ Female & 93 & 97.9 \\
$\quad$ Male & 02 & 2.1 \\
Age & & \\
$\quad<60$ years & 78 & 82.1 \\
$\quad \geq 60$ years & 17 & 17.9 \\
Marital Status & & \\
$\quad$ Single & 21 & 22.1 \\
$\quad$ Married & 53 & 55.8 \\
$\quad$ Widowed & 06 & 6.3 \\
Separated & 13 & 13.7 \\
$\quad$ Other & 02 & 2.1 \\
Years of School & & \\
$\quad \leq 9$ years & 50 & 52.6 \\
$\quad>9$ years & 45 & 47.4 \\
Family Income & & \\
$\quad 1$ minimum wage & 34 & 35.8 \\
2 a 5 minimum wages & 58 & 61.0 \\
$\quad>5$ minimum wages & 03 & 3.2 \\
Kinship & & \\
1st degree related or spouse & 71 & 74.7 \\
$\quad$ Others \\
Health Problems & 24 & 25.3 \\
Yes & & \\
$\quad$ No & 82 & 86.3 \\
Total & 13 & 13.7 \\
\hline
\end{tabular}

Note: Survey data.

\section{Discussion}

The results of this study show some characteristics of caregivers' profile that are in line with data from the national and international literature, showing that care is done mostly by women aged around
Ninety three caregivers said they didn't perform other activity besides care giving, exercising it informally without receiving any compensation. The median time found among them, regarding how long they play the role of caring for their relatives was 36 months. The minimum time reported by them was four months and they reported a maximum time of 408 months.

Among the health problems mentioned by 82 caregivers, the most mentioned were back problems and anxiety (Figure 1).

Table 2 - Characteristics of caregivers, Home Care Service in relation to caregiving activities. Goiânia - G0, 2013

\begin{tabular}{lll}
\hline Characteristics & $\mathbf{n}$ & (\%) \\
\hline $\begin{array}{l}\text { Previous experience } \\
\text { in care }\end{array}$ & & \\
Yes & 15 & 15.8 \\
No & 80 & 84.2 \\
Shift of care & \\
$\quad$ Just one shift & 10 & 10.5 \\
$\quad$ More than one shift & 85 & 89.5 \\
$\begin{array}{l}\text { Divide the caregiver } \\
\text { work with others } \\
\text { Yes }\end{array}$ & & \\
$\quad$ No & 58 & 61.1 \\
Hours dispensed in the & 37 & 38.9 \\
caregiver role & & \\
Up to 12 hours & 29 & 30.5 \\
$\quad$ More than 12 hours & 66 & 69.5 \\
Weekly days off & & \\
Yes & 15 & 15.8 \\
No & 80 & 84.2 \\
Total & 95 & 100 \\
\hline
\end{tabular}

Note: Survey data.

50 years old, married and which are first-degree relatives or spouse of the patient in monitoring and home care (19 - 27).

Although there was emancipation of women in the social and professional spheres, it is noticed that the care giving is still tied to the female figure, leading to 
women the responsibility for taking care of children, of the house, of the companion and also of the sick family member. In addition to that, around the age of 50 , when many women reach the end of the reproductive stage, culturally they become considered as the main providers of health care for the family (28 - 30).

Of the ninety-five caregivers surveyed only two are considered formal, that is receive remuneration for exercising the function. Informality in the care giving process stands out in other studies about this subject, indicating that the caregiver figure occurs within the family, mainly for financial reasons, and there is this dynamic social process and implicit history, which reinforces the care as a family obligation $(31,32)$.

The fact that most caregivers are first-degree relatives or spouse of the monitoring and home care patient leads to reflect on the changes that have occurred in family arrangements can interfere in this care giving process. In the contemporary world, there are several existing forms of family organization, and these continually change in order to satisfy the needs imposed by society (33).

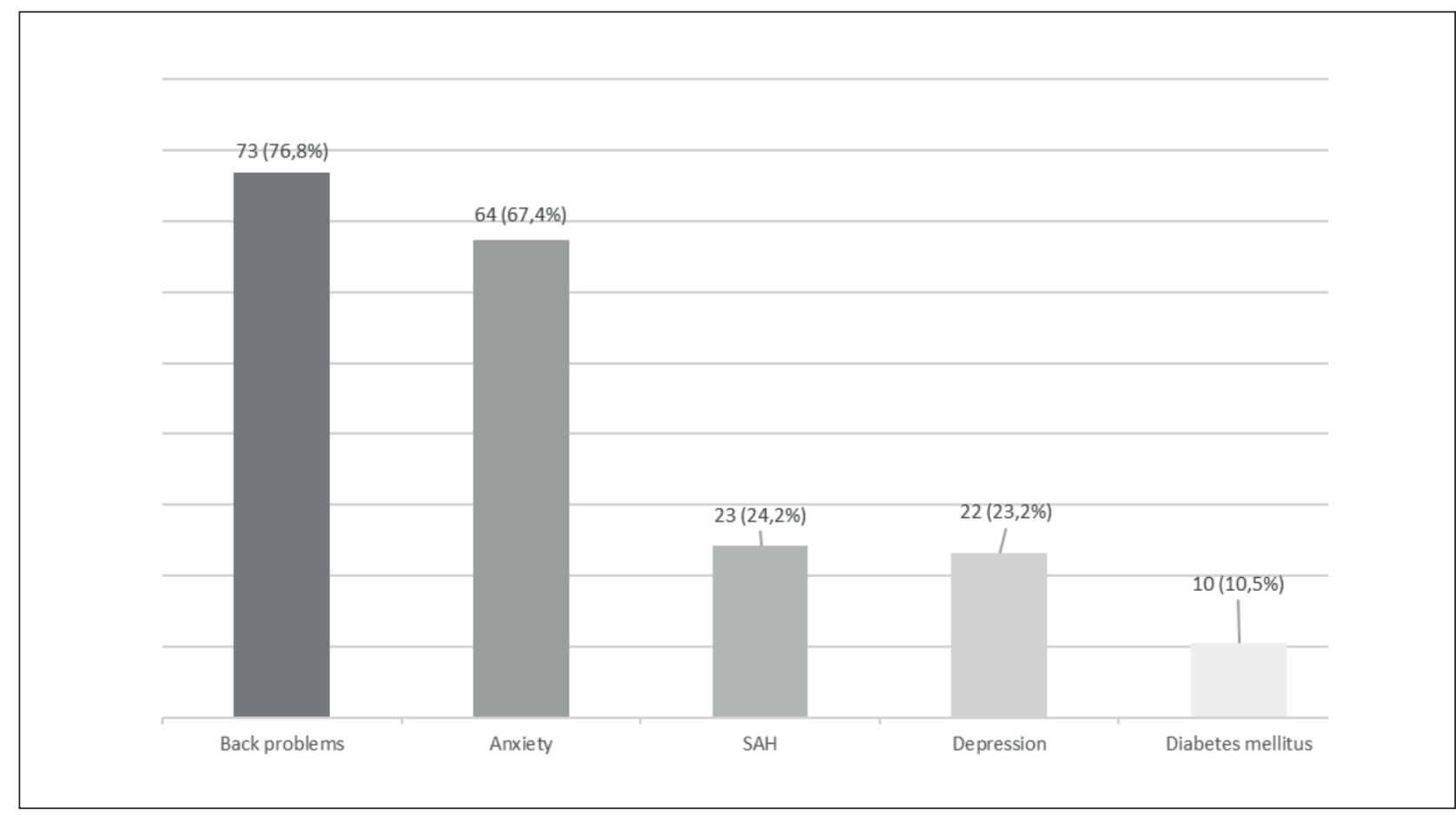

Figure 1 - Distribution of health problems presented by the caregivers of the Home Care Service. Goiânia - G0, 2013. Note: Survey data.

As a result, provide a concept for "family" and define its roles, it has become quite complex. Different forms of family gain visibility, as the extended family, the recomposed and the families formed by pregnancy by scientific methods or by single parents. The manner they relate to each other is also presented in different ways. This implies redefinition of roles and redistribution of responsibilities among the family members (34).

In view of home care a challenge is presented: who will take care of the functionally dependent patient, in this new family model? It points out the need for public policies for the family as a whole, with actions departing from the principle that this institution is not reduced to a space of care giving, but that it is also a space to take care of (33).

Although social assistance is a right guaranteed by the Constitution, concerning the dimension of care giving, that right ends because it does not materialize due to inconsistent and poorly coordinated government actions. The policies in this area are focused on income transfer programs, and in relation to care giving, they are the result of residual activities and guided by the institutionalization of poor elderly (8).

In health care area this reality is not very different. The lack of institutions to provide assistance to fully 
dependents individuals makes the ultimate responsibility rests with the family. Initiatives such as the Best Home program, in which the SAD is included, seem to contribute to change this scenario. They work with the prerogative to instruct caregivers, enabling them and welcoming their doubts to increase their skills and optimize the care provided to the user. However, this care model seems to bring impact on the figure of the caregiver and should be assessed, since it was later incorporated into the Unified Health System and is a relatively new proposal, still in the implementation process across the health network.

One aspect that should be considered is the fact that most of the caregivers addressed in this study reported at least one health problem. The back problems are the main complaint, corroborating other studies that also show that back problems were also prevalent $(17,35)$.

The job of caregiving usually has uninterrupted character, that is, without rest, leading the caregiver to work for straight hours, especially with activities such as body care, feeding, elimination, environment, health control and other situations. The caregiver can experience situations of overload and stress (36).

When the caregivers have changes in their health the care process is compromised, thus it does not reach its fullness or meet the needs of people who are submitted to their care. Therefore, the caregivers also need to be heard, taking care and supported with priority, so their quality of life can be ensured (37).

In this study, although the average age of the caregivers was 49.7 years, there is the presence of 17 elderly caregivers. This situation is another serious problem: elderly people caring for the elderly, since most of SAD users are in this age group.

About $40 \%$ of the people who take care of elderly in the city of São Paulo, are also elderly. This may be a sign of population aging, in addition to families with fewer children and the greater presence of women in the labor market, which reduces the supply of caregiving at home (38).

Although aging is not a disease, changes in structures and bodily functions which occur in the organism, primarily in musculoskeletal system, skeletal system and nervous system, cause individuals to lose their functional capacity, which can be exacerbated by the process of caring for others $(39,40)$.

Another aspect that highlights the need to reformulate the current health system in regard to home care, and that affects the daily lives of most caregivers families is the financial difficulty of the poorest population. In this study the situation became evident as most of caregivers of SAD users are first-degree relative or spouse. In addition, they have low income and cannot afford to hire professionals to perform the rotation in this function. This explains the fact that most of them do not enjoy off periods during the week and dispenses long hours in caregiving activity, a result similar to other studies that identified caregivers with dedication of more than 8 hours a day and also caregivers that make a workload of 16 and 24 hours per day $(12,32)$.

According to another study many caregivers are unemployed and survive with the income from the patient retirement. In many cases, they are insufficient to meet the basic needs of the patient (41).

While recognizing that the provision of care should be the responsibility of families, the government and the private market, states should be the driving part of this offer in order to anticipate the needs of care that go beyond health care and ensure that these resources are available and distributed in an equitable and efficient manner (42). Thus, it is necessary that the government very soon, provide alternative care for functionally dependent people.

\section{Conclusion}

The findings of this study lead to a broader reflection on the Brazilian health system regarding the organization of primary care in the sphere of home care, which gives priority to reducing the demand for hospital care and period of hospitalization for ensure the humanization of the caregiving performed at home.

Changes in the health system with the prioritization of home care have highlighted the public dimension of caregiving activity and the essential role of caregiver facing the phenomenon of population aging. This implies increased demand for caregivers, especially for the population that depend exclusively on the public health service. In such cases, this demand has been met by a member of the family or of the community, given the financial difficulties of obtaining a formal caregiver.

The state's stance (that reinforces in its public policies the caregiving as something natural within families) needs to be reviewed. Notwithstanding the implications for social security and health system 
that this aging panorama causes, the new family profile cannot alone address this growing demand for caregiving.

This theme should be in the agenda of public administrators, because the current situation points to the need for a restructuring of public policies regarding the social support network for caregivers families of functionally dependent patients.

Growing old is an achievement. However, aging with quality of life is essential. Health systems and social protection systems must adapt to the new reality, with actions that understand this complex scenario and not just delegate to the families responsibility for the care, but that supply their needs and ensure to all its members better living and health conditions.

\section{References}

1. Floriano LA, Azevedo RCS, Reiners AAO, Sudré MRS. Cuidado realizado pelo cuidador familiar ao idoso dependente, em domicílio, no contexto da Estratégia Saúde da Família. Texto Contexto Enferm. 2012; 21(3):543-8.

2. Lima-Costa MF, Veras R. Saúde pública e envelhecimento. Cad Saude Publica. 2003;19(3):700-1.

3. Secretaria de Direitos Humanos. Secretaria Nacional de Promoção e Defesa dos Direitos Humanos. Dados sobre o envelhecimento no Brasil. [cited 2015 Mar 10]. Available from: http://tinyurl.com/hhjwo9d. Portuguese.

4. Veras R. Envelhecimento populacional contemporâneo: demandas, desafios e inovações. Rev Saude Publica. 2009;43(3):548-54.

5. Schmidt MI, Duncan BB, Silva GA, Menezes AM, Monteiro CA, Barreto SM, et al. Doenças crônicas não transmissíveis no Brasil: carga e desafios atuais. Saúde no Brasil. Lancet. 2011;377(9782):1949-79.

6. Rates HF. Cuidado de saúde do idoso no domicílio: implicações para as cuidadoras no Distrito Ressaca Município de Contagem/MG [master's thesis]. Belo Horizonte (Brazil): Universidade Federal de Minas Gerais; 2007. Portuguese.

7. Veras RP. Experiências e tendências internacionais de modelos de cuidado para com o idoso. Cienc Saude Colet. 2012;17(1):231-8.
8. Camarano AA. Cuidados de longa duração para a população idosa: um novo risco social a ser assumido? In: Hirata H, Guimarães NA (Orgs.). Cuidado e cuidadoras: as várias faces do trabalho do care. São Paulo: Atlas; 2012. p. 148-65. Portuguese.

9. Camarano AA, Kanso S. Como as famílias brasileiras estão lidando com idosos que demandam cuidados e quais as perspectivas futuras? A visão mostrada pelas PNADS. In: Camarano AA (Org.). Cuidados de longa duração para a pessoa idosa: um novo risco social a ser assumido? Rio de Janeiro: Ipea; 2010. Portuguese.

10. Nickel R, Lima AP, Navarro EJ, Pinto LM, Teive HAG, Becker N. Correlação entre a qualidade de vida de cuidadores familiares e os níveis de independência funcional dos cuidados. Cogitare enferm. 2010;15(2):225-30.

11. Amendola F, Oliveira MAC, Alvarenga MRM. Qualidade de vida dos cuidadores de pacientes dependentes no programa de saúde da família. Texto Contexto Enferm. 2008;17(2):266-72.

12. Flores E, Rivas E, Seguel F. Nivel de sobrecarga en el desempeño del rol del cuidador familiar de adulto mayor con dependencia severa. Cienc enferm. 2012;18(1):29-41.

13. Ministério da Saúde. Portaria 2.029, de 24 de agosto de 2011. Institui a Atenção Domiciliar no âmbito do Sistema Único de Saúde (SUS). Brasília: Ministério da Saúde; 2011. Portuguese.

14. Brasil. Ministério da Saúde. Portaria 963, de 27 de maio de 2013. Redefine a Atenção Domiciliar no âmbito do Sistema Único de Saúde (SUS). Brasília: Ministério da Saúde; 2013. Portuguese.

15. Saúde Goiânia. Jornal da Secretaria Municipal de Saúde de Goiânia. 2011 [cited 2012 Nov 15]. Available from: http://tinyurl.com/z2g45br.

16. Ministério da Saúde. Conselho Nacional de Saúde. Resolução n. 966 de 12 de dezembro de 2012. Diretrizes e normas regulamentares da pesquisa envolvendo seres humanos. Brasília: Ministério da Saúde; 2013. Portuguese.

17. Oliveira DC, Carvalho GSF, Stella F, Higa CMH, D'Elboux MJ. Qualidade de vida e sobrecarga de trabalho em cuidadores de idosos em seguimento ambulatorial. Texto Contexto Enferm. 2011;20(2):234-40. 
18. Gratão ACM, Vendruscolo TRP, Talmelli LFS, Figueiredo LC, Santos JLF, Rodrigues RAP. Sobrecarga e desconforto emocional em cuidadores de idosos. Texto Contexto Enferm. 2012;21(2):304-12.

19. Cramm JM, Strating MMH, Nieboer AP. Satisfaction with care as a quality-of-life predictor for stroke patients and their caregivers. Qual Life Res. 2012;21(10):1719-25.

20. Dominguez-Sosa G, Zavala-González MA, Cruz-Méndez DC, Ramiréz-Ramírez MO. Síndrome de sobrecarga en cuidadores primarios de adultos mayores de Cárdenas, Tabasco, México: Enero a mayo de 2008. Med UIS. 2010;23(1):28-37. Spanish.

21. Ferreira F, Pinto A, Laranjeira A, Pinto AC, Lopes A, Viana A, et al. Validação da escala de Zarit: sobrecarga do cuidador em cuidados paliativos domiciliários, para a população portuguesa. Cadernos de Saude. 2010;3(2):13-9.

22. Graça A, Nascimento MA, Lavado EL, Garanhani MR. Qualidade de vida de cuidadores familiares de pessoas com lesão da medula espinhal. Rev Bras Enferm. 2013;66(1):79-83.

23. Grandón P, Saldivia S, Melipilán R, Pihan R, Albornoz E. Adaptación y validación de la Entrevista de Carga familiar Objetiva y Subjetiva (ECFOS) en población chilena. Rev Chil Neuropsiquiatr. 2011;49(4):320-30.

24. Kenny PM, Hall JP, Zapart S, Davis PR. Informal care and home-based palliative care: the health-related quality of life of cares. J Pain Symptom Manage. 2010;40(1):35-48.

25. Moreira PHB, Mafra SCT, Pereira ET, Silva VE. Qualidade de vida de cuidadores de idosos vinculados ao Programa Saúde da Família - Teixeiras, MG. Rev Bras Geriatr Gerontol. 2011;14(3):433-40.

26. Moreno JAM, Arango-Lasprilla JC, Rogers H. Necesidades familiares y su relacíon con las características psicosociales que presentan los cuidadores de personas con demencia. Psicologia desde el Caribe. 2010;(26):1-35. Spanish.

27. Nardi T, Rigo JC, Brito M, Santos ELM, Bós AJG. Sobrecarga e percepção da qualidade de vida em cuidadores de idosos do Núcleo de Atendimento à Terceira Idade do Exército (Natiex). Rev Bras Geriatr Gerontol. 2011;14(3):511-9.
28. Favero L. Cuidado com a mãe/mulher cuidadora. In: Lacerda MR, Costenaro RGS (Orgs.). Quem cuida de quem cuida? As teias de possibilidades de quem cuida. 3rd ed. Porto Alegre (Brazil): Moriá; 2013. p.57-69. Portuguese.

29. Rondini CA, Justo JS, Filho FST, Lucca JAC, Oliveira PA. Análise das relações entre qualidade de vida e sobrecarga de cuidadoras de idosos de Assis, SP. Estud Pesqui Psicol. 2011;11(3):796-820.

30. Wegner W, Pedro ENR. Os múltiplos papéis sociais de mulheres cuidadoras-leigas de crianças hospitalizadas. Rev Gaucha Enferm. 2010;31(2):335-42.

31. Alvarez E, Gallegos S, Romero E, Moraga C, López M, Estalleda C, et al. Impacto de intervención temprana a cuidadores de pacientes secuelados de un accidente cerebro vascular. Estudio piloto. Rev Chil Ter Ocup. 2011;11(2):23-33. Spanish.

32. Aravena VJ, Alvarado OS. Evaluación de la sobrecarga de cuidadoras/es informales. Cienc Enferm. 2010;16(2):111-20. Spanish.

33. Mioto CRT. Cuidados sociais dirigidos á família e segmentos sociais vulneráveis. In: Capacitação em serviço social e política social. Módulo 4: 0 trabalho do assistente social e as políticas sociais. Brasília: UNB/ Centro de Educação Aberta, Continuada a Distância; 2000. Portuguese.

34. Biroli F. Família: novos conceitos. São Paulo: Editora Fundação Perseu Abramo; 2014. Portuguese.

35. Santos NMF. Qualidade de vida e sobrecarga de estresse do cuidador de idoso com histórico de acidente vascular encefálico [master's thesis]. Uberlândia (Brazil): Universidade Federal do Triângulo Mineiro; 2010. Portuguese.

36. Luzardo AR, Gorini MIPC, Silva APSS. Características de idosos com doença de Alzheimer e seus cuidadores: uma série de casos em um serviço de neurogeriatria. Texto Contexto Enferm. 2006;15(4):587-94.

37. Silva JMON. Sintomatologia psiquiátrica do cuidador informal [master's thesis]. Porto (Portugal): Escola Superior de Enfermagem do Porto; 2011. Portuguese.

38. Collucci C. Cresce o número de idosos que cuidam de idosos doentes. In: Folha de São Paulo. 2014 [cited 2015 Mar 14]. Available from: http://tinyurl.com/ jlz88bu. Portuguese. 
39. Nogueira SL. Capacidade funcional, nível de atividade física e condições de saúde de idosos longevos: um estudo epidemiológico [master's thesis]. Viçosa (Brazil): Universidade Federal de Viçosa; 2008. Portuguese.

40. Rodrigues SLA, Watanabe HAW, Dernti AM. A saúde de idosos que cuidam de idosos. Rev Esc Enferm USP. 2006;40(4):493-500.

41. Gonçalves LHT, Alvarez AM, Sena ELS, Santana LWS, Vicente FR. Perfil da família cuidadora de idoso doente/ fragilizado do contexto sociocultural de Florianópolis, SC. Texto Contexto Enferm. 2006;15(4):570-7.
42. World Health Organization. Ethical choices in longterm care: what does justice require? World Health Organization Collection on Long-Term Care; 2002.

Received in 06/04/2015

Recebido em 04/06/2015

Approved in 06/07/2016

Aprovado em 07/06/2016 